\title{
Caution is needed in interpreting the results of comparative studies regarding oncological operations by minimally invasive versus laparotomic access
}

\section{É necessário cautela na interpretação dos resultados de estudos comparativos de cirurgias oncológicas por acessos minimamente invasivos vs laparotômicos}

Pedro Ricardo de Oliveira Fernandes, TCBC-SP ${ }^{1}$ id ; Francisco Américo Fernandes Neto, eCBC-SP2; Durval Renato Wohnrath, TCBC-SP3; VINÍCIUS de LIMA VAZQUez 3 .

\section{A B S T R A C T}

\begin{abstract}
We aim to alert the difference between groups while comparing studies of abdominal oncological operations performed either by minimally invasive or laparotomic approaches and potential conflicts of interest in presenting or interpreting the results. Considering the large volume of scientific articles that are published, there is a need to consider the quality of the scientific production that leads to clinical decision making. In this regards, it is important to take into account the choice of the surgical access route. Randomized, controlled clinical trials are the standard for comparing the effectiveness between these interventions. Although some studies indicate advantages in minimally invasive access, caution is needed when interpreting these findings. There is no detailed observation in each of the comparative study about the real limitations and potential indications for minimally invasive procedures, such as the indications for selected and less advanced cases, in less complex cavities, as well as its elective characteristic. Several abdominal oncological operations via laparotomy would not be plausible to be completely performed through a minimally invasive access. These cases should be carefully selected and excluded from the comparative group. The comparison should be carried out, in a balanced way, with a group that could also have undergone a minimally invasive access, avoiding bias in selecting those cases of minor complexity, placed in the minimally invasive group. It is not a question of criticizing the minimally invasive technologies, but of respecting the surgeon's clinical decision regarding the most convenient method, revalidating the well-performed traditional laparotomy route, which has been unfairly criticized or downplayed by many people.
\end{abstract}

Keywords: Surgical Oncology. Selection Bias. Laparoscopy. Conversion to Open Surgery.

\section{CONTENT}

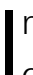

n some laparotomic surgeries, the extent and location of the incision, in addition to intracavitary manipulation, may represent unnecessary, therefore preventable, trauma, following the old and false surgical adage: "great incisions, great surgeons".

There is no standard, homogeneous and adequate practice of postoperative analgesia (blockages, parenteral, enteral, oral - preventive, peremptory or therapeutic) disseminated in the daily lives of most hospitals. Nor are there regular and efficient physical therapy care in the routine of many centers. Both practices can minimize major adverse events, which can be avoided or mitigated in patients undergoing laparotomy.

Some minimally invasive surgeries result in less bleeding, as they are usually compared with laparotomic surgeries without the use of high-tech hemostatic forceps and staplers, among other special devices, used in minimally invasive approaches, but which can and should also be used in laparotomies.

Major bleeding in laparotomic surgeries, in the general reckoning of comparative studies, can represent situations of greater complexity that could not be solved by the minimally invasive route. In fact, when there are major hemorrhagic or other complex complications during a minimally invasive surgery, there is usually a disorderly conversion to "maximized" laparotomy surgery, sometimes with unfavorable outcomes ${ }^{1}$.

1 - Hospital Santa Ignês - Indaiatuba - SP; Samaritano Hospital de Campinas, Oncology Surgery - Campinas - SP - Brazil 2 - Hospital Municipal Dr Mário Gatti, Oncology Surgery - Campinas - SP - Brazil 3 - Hospital de Amor de Barretos (Barretos Cancer Hospital - PIO XII Foundation), Surgery Oncology - Barretos - SP - Brazil 
Surgeries initiated by minimally invasive access and converted to laparotomy access due to some intraoperative limitation cannot be considered merely as one more procedure by laparotomy. This contaminates this group's statistics (crossover), because if they had been performed through laparotomic access from the beginning, the transoperative and, consequently, the postoperative outcomes could be different. In addition, one should consider the fact that it was not feasible to perform them through a minimally invasive access ${ }^{2,3}$.

The selection for minimally invasive surgeries is usually made up of less complex cases, even within the same oncological stage $\mathrm{e}^{2,4,5,6,7}$. Patients at an earlier stage and with less comorbidity, the majority of those submitted to minimally invasive access, tend to have display outcomes, unlike the more complex and complicated ones, which are common in groups of patients submitted to laparotomic procedures $2,4,6,9$.

The lack of touch, in some situations of oncological dissections by minimally invasive accesses, can cause dissection or resection below or even beyond what is necessary (in peritoneal carcinomatosis, retroperitoneum, advanced pelvic endometriosis, multivisceral adhesions, and/or the vicinity of noble structures, etc.).

Just because minimally invasive surgery can be performed does not mean it should ${ }^{10}$. In some situations, such as with cancer of the cervix treated by minimally invasive access, there may be worse cancer outcomes than those that occur by laparotomy ${ }^{5}$. This is possibly due to greater tumor manipulation and/or due to a difference in the pattern of dissection, resection and surgical oncological hygiene on a disease in which locoregional surgical treatment is essential for the final outcome.

In qualified hands, especially in pelvic surgeries with incisions limited to the infraumbilical or suprapubic region, and in operations for enteral catheterization by minilaparotomy ${ }^{11}$, especially when respecting the access through the Linea Alba and limiting the aforementioned biases, postoperative outcomes in both groups may be closer.

Conflicts of interest can go unnoticed ${ }^{12}$ when there are greater offerings of technologies, marketing, media, commerce, cosmetics, exhibitionism and fame.

Surgeries of lesser complexity can also be performed through parsimonious, moderately invasive laparotomic accesses, through smaller, more appropriate, less traumatic incisions and manipulations, with fruitful clinical, analgesic, anti-inflammatory, nutritional and physical therapy post-operative assistance, approaching the results of minimally invasive accesses. So we perceive in our practice.

In several cases, with a small increase in the total dimension of the incisions of the minimally invasive accesses (sum of the dimensions of the incisions for inserting the trocars and removing the specimen), surgery can be performed in the laparotomic form with an appropriate incision to the procedure in question, observing technical and oncologic safety, moderate invasiveness, less complexity, shorter time and lower costs.

The few randomized, controlled and wellconducted studies show no inferiority of some recognized and limited advantages of minimally invasive access for abdominal cancer resections. In selected situations, they are more appropriate, what should not, however, induce the non-realization or discredit of laparotomic accesses of adequate extension. These are quite economical and safe in hands and minds skilled in highly complex cancer surgery ${ }^{13}$, inseparable from a broad multidisciplinary and multiprofessional perioperative care. The choice of the surgeon (and team) should prevail over the choice of the surgical access method ${ }^{14}$.

According to Dipen Parekh, director of robotic surgery at the University of Miami, "Just because something is new [or more technological and modern - our addendum] doesn't necessarily mean it is better [or that it replaces the traditional way - our addendum]. We need to be making evidence-based decisions instead of marketing-based [or passion-based - our addendum] decisions". The results show that open surgery remains a good option and that the surgeon's experience is what matters $^{13}$. At the moment, according to Marcus Sadi, coordinator of the Uro-Oncology area at the Escola Paulista de Medicina, "the best cost-benefit is conventional surgery with an experienced multidisciplinary team"13.

Perhaps, the heart of the matter is the choice of a more expensive and elective method at a disadvantage to the investment in access to fruitful assistance and cancer prevention to the majority of our needy 
population. Thus, "truths" such as incisions of adequate size, through technological access, with lower morbidity and early discharges may be secondary or more limited.

We need more randomized, controlled, clinical trials with high methodological quality (clear, balanced and detailed methodological design, adequate eligibility criteria for selecting homogeneous groups that can receive either of the two interventions, randomization, control for biases and limitations) and systematic reviews that use rating scales to analyze methodological quality, free of conflicts of interest.

There is no demerit to those who continue performing highly complex oncological surgeries through an adequate laparotomic access.

\title{
R E S U M O
}

\begin{abstract}
Objetivamos alertar a desigualdade entre grupos de pacientes, em estudos comparativos de cirurgias oncológicas abdominais por acessos minimamente invasivos ou laparotômicos, e os possiveis conflitos de interesse na demonstração ou interpretação dos resultados. Diante do grande volume de artigos científicos produzidos, há necessidade de se considerar a qualidade da produção científica de estudos para a tomada da decisão clínica quanto à eleição da via de acesso cirúrgico. Ensaios clínicos randomizados e controlados são o padrão para comparar a eficácia entre estas intervenções em situações diversas. Apesar de alguns estudos indicarem vantagens no acesso minimamente invasivo, é preciso cautela na interpretação desses achados. Não se percebe detalhada discussão que alerte, em cada estudo comparativo, sobre os reais limites e indicações possíveis de cirurgias minimamente invasivas, como indicações para casos selecionados, menos avançados, mais eletivos, e em cavidades menos complexas. Diversas cirurgias oncológicas abdominais via laparotômica não seriam plausíveis de serem, completamente, realizadas por acesso minimamente invasivo. Estas deveriam ser, criteriosamente, selecionadas e excluídas do grupo comparativo. A comparação deve ser, equilibradamente, realizada com grupo que, muito provavelmente, também poderia ter sido submetido ao acesso minimamente invasivo a contento, evitando viés de seleção da concentração de casos de complexidade menor no grupo da cirurgia minimamente invasiva. Não se trata, aqui, de desmerecer as tecnologias minimamente invasivas, mas de respeito à decisão clínica do cirurgião pelo método mais conveniente, revalidando a via laparotômica tradicional bem procedida, a qual tem sido, injustamente, criticada ou inferiorizada por muitos em nosso meio.
\end{abstract}

Palavras chave: Oncologia Cirúrgica. Viés de Seleção. Laparoscopia. Conversão para Cirurgia Aberta.

\section{REFERENCES}

1. Bastawrous AL, Landmann RG, L, Liu Y, Liu E, Cleary RK. Incidence, associated risk factors, and impact of conversion to laparotomy in elective minimally invasive sigmoidectomy for diverticular disease. Surg Endosc. 2019;34(2):598-609.

2. Denbo JW, Marmor S, Jensen EH. Minimally invasive lymphadenectomy for biliary tumors: stepwise progress. Ann Surg Oncol. 2019;26(6):1592-93.

3. Garas G, Markar SR, Malietzis G, Ashrafian H, Hanna $G$, Zacharakis $E$, et al. Induced bias due to crossover within randomised controlled trials in surgical oncology: a meta-regression analysis of minimally invasive versus open surgery for the treatment of gastrointestinal cancer. Ann Surg Oncol. 2018;25:221-30.

4. Bard I, Rooij T, Van Hilst J, Diener MK, Allen P, Vollmer $\mathrm{CL}$, et al. Minimally invasive distal pancreatectomy on behalf of the Organizing Committee for the State of the Art Conference on Minimally Invasive Pancreas Resection. HPB. 2017;19:205-14.
5. Ramirez PT, Frumovitz M, Pareja R, Lopez A, Vieira M, Ribeiro $R$, et al. Minimally invasive versus abdominal radical hysterectomy for cervical cancer. N Engl J Med. 2018;379(20):1895-904.

6. Newman CM, Arnold SJ, Coull DB, Linn TY, Moran BJ, Gudgeon AM, et al. The majority of colorectal resections require an open approach, even in units with a special interest in laparoscopy surgery. Colorectal Disease. 2010;14(1):29-34.

7. Van Hilst J, Korrel M, de Rooij T, Lof S, Busch OR, Groot Koerkamp B, et al. Oncologic outcomes of minimally invasive versus open distal pancreatectomy for pancreatic ductal adenocarcinoma: a systematic review and meta-analysis. Eur J Surg Oncol. 2019;5(45):719-27.

8. Gani F, Goel U, Blair AB, Singh J, Overton HN, Meyer $C F$, et al. Minimally invasive versus open primary resection for retroperitoneal soft tissue sarcoma: a propensity-matched study from the National Cancer Database. Ann Surg Oncol. 2018;25(8):2209-17.

9. Taylor EF, Thomas JD, Whitehouse LE, Quirke P, Jayne D, Finan DF, et al. Population based study of 
laparoscopic colorectal cancer surgery 2006-2008. Br J Surg. 2013;100:553-60.

10. Gronchi A, Crago A, Raut CP. Minimally invasive surgery for retroperitoneal sarcoma: just because we can does not mean we should. Ann Surg Oncol. 2018;25:2129-31.

11. Petroianu A. Gastrostomia e jejunostomia por microincisão. Rev Bras Cir. 1986;86(4):161-3.

12. Wayant $C$, Turner $E$, Meyer $C$, Sinnet $P$, Vassar $M$. Financial conflicts of interest among oncologist authors of reports of clinical drug trials. JAMA Oncol. 2018;4(10):1426-28.

13. Parekh DJ, Isildinha M R, Castle EP, Gonzalgo ML,
Woods ME, Svatek, RS et al. Robot-assisted radical cystectomy versus open radical cystectomy in patients with bladder cancer (RAZOR): an open-label, randomised, phase 3, non-inferiority trial. Lancet. 2018 Jun 23; 391(10139): 2525-36 apud Azman, S. RAZOR: cistectomia radical robótica $X$ aberta. Onconews, 2018 Jun 28.

14. Yaxley JW, Coughlin GD, Chambers SK, Occhipinti $\mathrm{S}$, Samaratunga H, Zajdlewicz L, et al. Robot-assisted laparoscopic prostatectomy versus open radical retropubic prostatectomy: early outcomes from a randomised controlled phase 3 study. Lancet. 2016;388(10049):1057-66.
Received in: 14/01/2020

Accepted for publication: 09/04/2020

Conflict of interest: no.

Funding source: none.

\section{Mailing address:}

Pedro Ricardo de Oliveira Fernandes

E-mail: pedroricardo.oncocirurgia@gmail.com

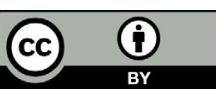

